\title{
Identifikasi Fenotipik Sapi Peranakan Angus di Kabupaten Sragen
}

\section{(Phenotype Identification of Angus Cross Cattle in Sragen Regency)}

\author{
Adinata $\mathrm{Y}^{1}$, Subiarta ${ }^{2}$, Aryogi ${ }^{1}$ \\ ${ }^{1}$ Loka Penelitian Sapi Potong, Jl. Pahlawan No. 2, Grati, Pasuruan, Jawa Timur \\ ${ }^{2}$ Balai Pengkajian Teknologi Pertanian Jawa Tengah, Jl. Soekarno Hatta Km. 26 No. 10, Bergas, Semarang \\ yudiku98@gmail.com
}

\begin{abstract}
Angus Cross cattle is one result of the artificial insemination (AI) program that is able to grow and adapt to tropical conditions particularly in Sragen Regency. The aim of this research was to obtain phenotypic data of Angus Cross cattle, as a basic data to its conservation, development and utilization. Research using survey method with observation, measurement and documentation of cows, interviews with stakeholders and smallholder farmers, which were conducted in five districts in Sragen Regency. The data obtained are presented descriptively. The results showed that size of the Angus Cross cattle were higher for heart girth (HG), hip height (HH) and body length (BL) than other local cattle in Indonesia. Its phenotypic a mixture of Aberdeen Angus, American Brahman and Ongole Cross cattle. Angus Cross cattle has rapid growth, advance reproduction performance, ability to use low quality feed and tolerant to tropical environment. Angus Cross cattle can be used for breeding program as beef cattle. Angus Cross cattle can be promoted as a new breed candidate of Indonesia beef cattle.
\end{abstract}

Key Words: Phenotype, Angus Cross Cattle, Candidate Breed, Sragen Regency

\begin{abstract}
ABSTRAK
Sapi Peranakan Angus merupakan salah satu hasil pelaksanaan program IB yang mampu berkembang dan beradapatasi di daerah tropis khususnya di Kabupaten Sragen. Penelitian ini bertujuan mendapatkan data fenotipik sapi Peranakan Angus, sebagai data dasar guna menyusun konsep pelestarian, pengembangan dan pemanfaatannya. Penelitian menggunakan metode survei dengan pengamatan, pengukuran dan dokumentasi sapi, serta wawancara langsung dengan pihak terkait, yang dilakukan di lima kecamatan di kabupaten Sragen. Data yang diperoleh disajikan secara deskriptif. Hasil penelitian menunjukkan bahwa sapi Peranakan Angus memiliki Lingkar Dada (LG), Tinggi Gumba (TG) dan Panjang Badan (PB) lebih tinggi dibandingkan sapi lokal lainnya di Indonesia. Fenotipik sapi Peranakan Angus merupakan gabungan dari tetua yang diduga membentuk sapi Peranakan Angus yaitu Aberdeen Angus, American Brahman dan Peranakan Ongole. Sapi Peranakan Angus mempunyai keunggulan pertumbuhan yang cepat, performa reproduksi yang baik, kemampuan memanfaatkan pakan berkualitas kurang baik dan toleran terhadap lingkungan tropis. Sapi Peranakan Angus dapat digunakan untuk program pemuliaan sebagai penghasil daging serta dapat diarahkan menjadi kandidat rumpun baru sapi potong Indonesia.
\end{abstract}

Kata Kunci: Fenotipik, Sapi Peranakan Angus, Kandidat Rumpun, Kabupaten Sragen

\section{PENDAHULUAN}

Indonesia sudah mengenal teknologi Inseminasi Buatan (IB) sejak tahun 1952, aplikasi di peternak rakyat dimulai tahun 1969 dengan menggunakan semen cair. Pada tahun 1976 diikuti dengan pendirian Balai Besar Inseminasi Buatan (BBIB) Lembang untuk memproduksi dan menyebarkan semen beku dari sapi asli dan lokal Indonesia serta sapi impor. Tiga pokok alasan pelaksanaan program IB adalah: (1) Cara yang murah dalam 
meningkatkan mutu genetik sapi; (2) Cara yang paling cepat dalam transformasi dan konfigurasi genetik populasi ternak; dan (3) Alternatif murah dan cepat dari program IB ini dapat diterapkan dalam skala massal (Siregar 1997).

Kegiatan IB pada sapi potong di Indonesia telah berkembang cukup luas, Namun arah dan tujuan dari program IB belum jelas, apakah ke arah pembentukan ternak komposit, terminal cross, atau ternak komersial. Perkembangan terkini peternak dibantu inseminator dalam kegiatan budidaya melakukan up grading ke arah bangsa sapi Bos taurus. Peternak sangat menyukai sapi crossbreed, karena harga jual anak jantan sangat tinggi (Diwyanto \& Inounu 2009). Namun, separuh dari pedet yang dihasilkan adalah sapi betina yang dipergunakan sebagai replacement. Sapi crossbreed hasil IB dengan sapi lokal yang semula merupakan sapi tipe kecil menjadi sapi tipe besar. Sebagian peternak mengalami kesulitan dalam penyediaan pakan bagi sapi betina produktif, sehingga sapi crossbreed ini kurus dengan kondisi tubuh yang tidak ideal sebagai sapi induk. Dampak dari kekurangan pakan ini secara nyata terindikasi akan menyebabkan penurunan kinerja reproduksi, seperti: nilai service per conception (S/C) yang tinggi, jarak beranak panjang, atau calf crop yang rendah. Kondisi ini biasanya dibarengi dengan produksi susu yang rendah dan kematian pedet yang tinggi (Diwyanto \& Inounu 2009). Hasil penelitian lain menunjukkan bahwa sapi persilangan dengan komposisi $\mathrm{F}_{1}$ atau crossbreed (50\% Bos taurus), Backcross 1 (75\% Bos taurus), Back-cross 2, (87,5\% Bos taurus), Back-cross 3 (>87,5\% Bos taurus), mempunyai conception rate (CR) secara berurutan: 68, 60, 39, dan 34\%, menunjukkan terjadi penuruan efisiensi reproduksi seperti yang disampaikan Putro (2009) di dalam Diwyanto \& Inounu (2009).

Kondisi yang berbeda terjadi di Kabupaten Sragen Provinsi Jawa Tengah. Perkembangan sapi hasil IB dengan menggunakan semen dari berbagai bangsa sapi Bos taurus, salah satunya ada yang disukai oleh petani peternak yaitu bangsa sapi Angus. Ciri utama dari turunan sapi Angus ini ada berwarna hitam. Sapi Peranakan Angus ini dikenal oleh masyarakat dengan sebutan sapi Hitam. Perkembangan sapi turunan persilangan dengan sapi Angus ini sangat baik karena mampu beradaptasi dengan kondisi lingkungan di Kabupaten Sragen dan koefisien teknis produksi dan reproduksi yang juga tetap baik. Hal ini sesuai dengan yang disampaikan oleh Astuti (2004) bahwa potensi biologis seekor ternak diukur berdasarkan kemampuan produksi dan reproduksinya dalam lingkungan pemeliharaan yang tersedia, karena data tersebut tidak terlepas dari pengaruh lingkungan tempat ternak dipelihara.

Berdasarkan uraian tersebut, penelitian ini dilaksanakan untuk mengidentifikasi dan mengkarakterisasi sapi Peranakan Angus sebagai salah satu dasar konservasi, program pemuliaan, pengembangan dan pemanfaatan sapi tersebut menjadi salah satu komoditas unggulan.

\section{MATERI DAN METODE}

Penelitian ini dilaksanakan melalui metode survei, yaitu pengamatan langsung sapi di peternak rakyat melalui pengukuran dimensi tubuh sapi, wawancara dengan pihak terkait yaitu peternak pelaku sejarah, Dinas Peternakan dan Perikanan Kabupaten Sragen, dan BIB Lembang. Penelitian dilakukan dalam rentang waktu 6 bulan mulai bulan Juni sampai November 2016 di Kecamatan Kedawung, Sidoharjo, Tanon, Plupuh dan Sragen Kota. Pemilihan lokasi didasarkan populasi terbanyak sapi Peranakan Angus.

Sebanyak 99 ekor sapi Peranakan Angus betina dengan umur berdasarkan kondisi gigi $\mathrm{I}_{0}, \mathrm{I}_{1}, \mathrm{I}_{2}, \mathrm{I}_{3}, \mathrm{I}_{4}$; diidentifikasi dan diukur dimensi tubuhnya yang meliputi lingkar dada (LD), tinggi gumba (TG), dan panjang badan (PB); kemudian ciri eksteriornya 
didokumentasikan. Karakteristik spesifik Peranakan Angus diperoleh dengan pengamatan secara langsung dan preferensi peternak atas keragaman sifat kualitatif.

Pengukuran tubuh menggunakan pita dan tongkat ukur, dilakukan saat sapi berdiri tegak (paralellogram). Ukuran LD diambil dengan cara mengikuti lingkaran dada/tubuh tepat di belakang bahu melewati gumba, TG diukur dari atas permukaan tanah sampai titik tertinggi gumba, sedangkan PB diukur dengan menarik garis horizontal dari tepi depan sendi bahu sampai ke tepi belakang bungkul tulang duduk. Skor kondisi tubuh diukur secara subjektif dengan nilai 1 sampai 5 (sangat kurus sampai dengan sangat gemuk) menurut Rutter et al. (2000). Data reproduksi berupa jarak beranak diketahui berdasar data catatan kelahiran. Data kuantitatif ditabulasi kemudian dianalisa dengan menghitung nilai rataan dan standar deviasinya.

\section{HASIL DAN PEMBAHASAN}

\section{Sejarah terbentuknya sapi Peranakan Angus}

Hasil wawancara dengan responden diketahui bahwa sejarah terbentuknya sapi Peranakan Angus di Kabupaten Sragen diawali dengan kebijakan pemerintah pada tahun 1976 untuk meningkatkan produktivitas sapi lokal menggunakan semen beku pejantan unggul American Brahman dan Aberdeen Angus dari Selandia Baru, Australia, Jerman dan Kanada yang didatangkan oleh pemerintah melalui Balai Inseminasi Buatan Lembang. Provinsi Jawa Tengah adalah salah satu provinsi yang ditetapkan untuk lokasi kegiatan introduksi teknologi reproduksi Inseminasi Buatan (IB). Kabupaten Sragen ditetapkan sebagai salah satu wilayah pelaksanaan IB yang menggunakan semen beku American Brahman dan Aberdeen Angus. Sebagian besar sapi yang ada di Kabupaten Sragen sebelum tahun 1976 adalah sapi Peranakan Ongole (PO) dan sisanya sapi Jawa. Kurun waktu 1976 sampai dengan 1982, lokasi pelaksanaan IB yang menggunakan semen beku American Brahman di Kabupaten Sragen adalah Kecamatan Tangen, Tanon, Jenar dan Gondang sedangkan semen beku Aberden Angus di wilayah Kecamatan Masaran.

Sapi keturunan hasil IB semen beku American Brahman berkembang dengan baik, masyarakat peternak menyebut sapi Benggala dan sebagian menyebutkan sapi Putih. Sapi tersebut mempunyai penampilan yang cukup besar, kekuatan otot yang baik, tidak mudah tergelincir dan pemeliharaan cukup mudah sehingga banyak digunakan sebagai tenaga kerja untuk menarik gerobak dan lori. Di Kabupaten Sragen pada saat itu ada pabrik gula yang membutuhkan transportasi untuk mengirimkan hasil panen tebu ke pabrik gula.

Sapi keturunan hasil IB semen beku Aberdeen Angus mempunyai penampilan warna tubuh hitam. Awalnya masyarakat peternak tidak menyukainya namun perkembangan berikutnya ternyata menarik minat masyarakat peternak karena sapi Peranakan Angus ini mempunyai sifat pertumbuhan yang lebih baik daripada Sapi PO. Pada waktu berikutnya sapi betina dengan warna hitam dapat bunting dan melahirkan pedet serta mempunyai kemampuan produksi susu yang cukup tinggi sehingga pertumbuhan pedetnya sangat baik dan hampir tidak ada kasus kematian pedet. Di sisi lain, sapi yang berwarna hitam dengan jenis kelamin jantan menunjukkan pertumbuhan yang baik sehingga mampu mencapai bobot potong lebih cepat dibandingkan dengan sapi PO. Kondisi ini akhirnya membuat sapi Hitam atau Peranakan Angus ini disukai oleh masyarakat peternak.

Mulai tahun 1982 sampai dengan 1992, penggunakan semen beku Aberdeen Angus diperluas ke wilayah Kecamatan Karangmalang, Gondang, Plupuh dan Sambungmacan. Wilayah pengembangan ini juga merupakan wilayah dari sapi Benggala (sapi Putih yang terbentuk dari IB semen beku American Brahman). Oleh karena itu, pada waktu tersebut di 
Kabupaten Sragen sudah terdapat populasi sapi Peranakan Angus dengan jumlah cukup banyak.

Pada tahun 1988 dan 1989, Balai Inseminasi Buatan Lembang mendatangkan sapi pejantan Brangus dari Tri S Ranch Tapos dan mulai memproduksi semen beku dari pejantan tersebut yang kemudian digunakan salah satunya di Kabupaten Sragen untuk mendukung perkembangan sapi Peranakan Angus yang ada di Kabupaten Sragen. Periode tahun 1992 sampai dengan 2001 pemerintah mulai memperkenalkan semen beku dari Bangsa sapi Simmental, Limousine dan Friesian Holland (FH). Semen beku dari ketiga bangsa sapi ini, diperkenalkan di Kabupaten Sragen, namun banyak masyarakat peternak yang menolaknya karena pedet yang dilahirkan berwarna coklat kemerahan (turunan Simental, Limousine) terkadang masyarakat peternak menyebutnya anak celeng (babi) dan berwarna belang hitam putih (turunan $\mathrm{FH}$ ) terkadang masyarakat peternak menyebutnya sapi Oto (sapi dengan temperamen galak).

Tahun 2001, Kabupaten Sragen mendapat 50 ekor sapi Betina Brangus melalui program Bantuan Presiden (Banpres). Sapi tersebut dikembangkan di Kecamatan Dayu. Namun dari 50 ekor induk tersebut hanya beranak 5-10 ekor dan pada tahun kedua sapi betina Brangus tersebut menurun menjadi 40 ekor (terdapat kematian 10 ekor) kemudian menyusut kembali menjadi 25 ekor. Usaha untuk menyelamatkan sapi betina Brangus ini dilakukan dengan menarik sapi tersebut dan dikumpulkan di Unit Pelaksana Teknis (UPTD) di bawah koordinasi Dinas Kabupaten Sragen. Namun karena perkembangannya kurang menggembirakan pada tahun 2012, sapi betina Brangus tersebut dihapus dari daftar aset.

Berdasarkan data di Dinas Peternakan dan Perikanan Kabupaten Sragen pada tahun 2008-2009, Kabupaten Sragen mendapatkan bantuan indukan Brahman Cross sejumlah 600 ekor dan disebarkan ke Kelompok Tani Ternak, namun perkembangannya juga tidak menggembirakan, akhirnya sapi Brahman Cross ini habis dengan sendirinya karena tidak dapat berkembang. Berdasarkan awal terbentuknya, diduga sapi Peranakan Angus ini mempunyai komposisi genetis berdasarkan bangsa sapi pembentuknya yaitu Aberdeen Angus, American Brahman dan Peranakan Ongole (PO).

\section{Karakteristik sapi Peranakan Angus}

Sapi Peranakan Angus mempunyai ciri-ciri khusus, karakteristik bersifat unik dan nilai kearifan lokal berhubungan keyakinan peternak dalam membudidayakannya (Tabel 1 \& Gambar 1). Ciri-ciri sapi Peranakan Angus yang disukai peternak adalah papag (rata) untuk bentuk bibir sebagai ciri sapi yang tidak pilih-pilih pakan, bembeng (seperti bentuk tabung) untuk bentuk leher pada jantan, kuwung (besar) untuk ukuran tulang iga, reden (bulu halus) untuk bentuk bulu pada betina yang menujukkan kemampuan mudah beranak berkali-kali, merit untuk bentuk ekor dari pangkal ekor tidak besar dan semakin kecil, gilig untuk ukuran kaki yang kecil dan pendek. Namun ada ciri yang tidak disukai oleh petani peternak yaitu di daerah dahi kepala ada warna putih yang artinya bahwa sapi tersebut agak susah pengendalian dan pemeliharaannya. Variasi yang ada dalam ukuran tubuh digunakan untuk mengevaluasi karakteristik morfostrukturalnya (Metta et al. 2004).

Berdasarkan sifat kualitatif dan karakteristik eksterior sapi Peranakan Angus tersebut di atas, maka diduga tetua sapi Peranakan Angus adalah hasil persilangan antara Aberdeen Angus, American Brahman dan PO. Hal ini sesuai dengan yang disampaikan oleh Delgado et al. (2001) bahwa langkah pertama dari karakterisasi sumber daya lokal genetik didasarkan pada pengetahuan tentang variasi dalam ciri-ciri morfologi. Karakterisasi bangsa ternak adalah pendekatan pertama untuk pemanfaatan berkelanjutan sumber daya genetik ternak (Lanari 2003). Manfaat lainnya adalah hasil dari program perbaikan genetik juga dapat dievaluasi secara morfologi (Riva et al. 2004). 
Tabel 1. Ciri-ciri sapi Peranakan Angus

\begin{tabular}{|c|c|}
\hline Sapi Peranakan Angus betina & Sapi Peranakan Angus jantan \\
\hline Berbulu tipis dan berwarna hitam & Berbulu tipis dan berwarna hitam \\
\hline Tidak mempunyai tanduk & Tidak mempunyai tanduk \\
\hline Tidak mempunyai punuk & Tidak mempunyai punuk \\
\hline Kepala relatif panjang dan besar & $\begin{array}{l}\text { Kepala relatif besar dan lebih pendek dibandingkan } \\
\text { dengan Sapi Sragen betina dengan sedikit bulu } \\
\text { diatas kepala }\end{array}$ \\
\hline Moncong relatif besar & Moncong relatif besar \\
\hline Kelopak mata kecil & Kelopak mata kecil \\
\hline $\begin{array}{l}\text { Telinga berukuran sedang dan aktif } \\
\text { bergerak tidak menggantung }\end{array}$ & $\begin{array}{l}\text { Telinga berukuran sedang dan aktif bergerak } \\
\text { tidak menggantung }\end{array}$ \\
\hline Punggung lurus dan lebar & Punggung lurus dan lebar \\
\hline $\begin{array}{l}\text { Bergelambir dengan ukuran kecil sampai } \\
\text { sedang dari rahang sampai depan dada }\end{array}$ & $\begin{array}{l}\text { Bergelambir dengan ukuran sedang dari rahang } \\
\text { sampai depan dada }\end{array}$ \\
\hline Dada relatif lebar dan dalam & $\begin{array}{l}\text { Dada relatif lebar, dalam dan relatif lebih besar } \\
\text { dari Sapi Sragen betina }\end{array}$ \\
\hline Tubuh cembung dan panjang & $\begin{array}{l}\text { Tubuh cembung, panjang dan relatif lebih besar } \\
\text { dari Sapi Sragen betina }\end{array}$ \\
\hline Kaki relatif kecil dan pendek & Kaki relatif kecil dan pendek \\
\hline Pantat berbentuk bulat & Pantat berbentuk bulat \\
\hline $\begin{array}{l}\text { Ekor berukuran sedang dan panjang dengan } \\
\text { bulu ekor relatif lebat }\end{array}$ & $\begin{array}{l}\text { Ekor berukuran sedang dan panjang dengan bulu } \\
\text { ekor relatif lebat }\end{array}$ \\
\hline Ambing berukuran besar & $\begin{array}{l}\text { Preputium dan penis berukuran besar dan skrotum } \\
\text { berukuran besar sedikit menggantung }\end{array}$ \\
\hline
\end{tabular}

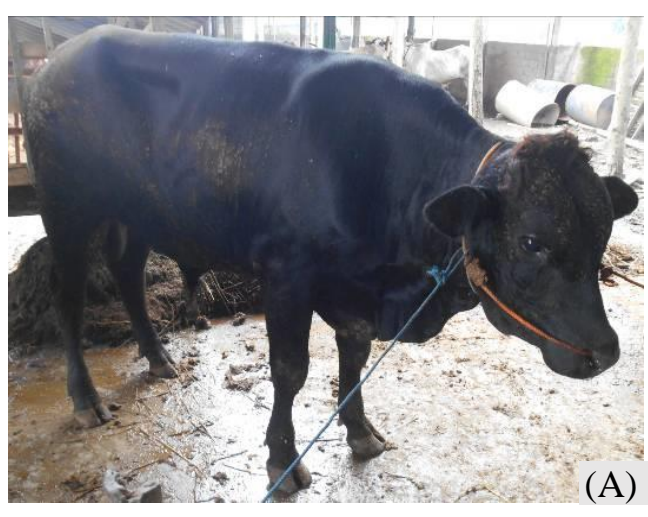

(A) Sapi Peranakan Angus jantan

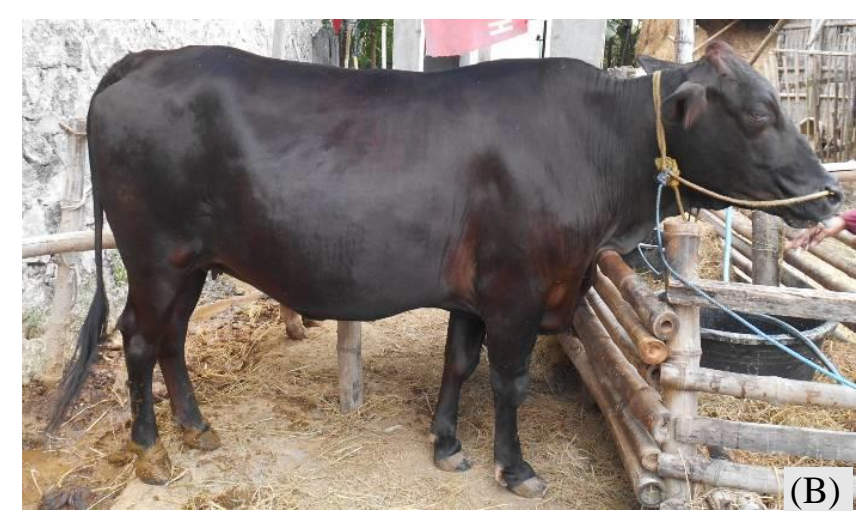

(B) Sapi Peranakan Angus betina

Gambar 1. Performa sapi Peranakan Angus jantan dan betina 


\section{Tampilan morfologi sapi Peranakan Angus}

Pengukuran morfologis sapi dilaksanakan untuk mengetahui ukuran kisaran optimal tubuh sapi sesuai kisaran umur berdasarkan kondisi gigi. Data yang diperoleh adalah sapi Peranakan Angus betina, karena di petani peternak jarang yang memelihara sapi Peranakan Angus jantan.

Berdasarkan Tabel 2 tampak bahwa LD, TG dan PB sapi Peranakan Angus dewasa $\left(\mathrm{I}_{4}\right)$ betina lebih besar dibandingkan dengan sapi betina sapi lokal lainnya. Berikut adalah nilai LD, TG dan PB dalam centimeter $(\mathrm{cm})$ secara berurutan dari sapi Rambon: $164,37 \pm 9,64 ; 118,88 \pm 7.89 ; 108,21 \pm 7,01$ (Adinata \& Aryogi 2015), sapi Madura: $142,50 \pm 7,00 ; 114,50 \pm 6,14 ; 116,75 \pm 10,24$ (Setiadi \& Diwyanto 1997), sapi PO: $162,15 \pm 12,33 ; 121,55 \pm 4,36 ; 109,75 \pm 9,72$ (Trifena et al. 2011), sapi Aceh: 140,0 $\pm 10,0$; 105,0 $\pm 70,0 ; 88,0 \pm 70,0$ dan sapi Bali: 152,3 $\pm 11,3 ; 111,7 \pm 5,6 ; 113,9 \pm 5,6$ (Adrial 2010).

Tubuh sapi Peranakan Angus lebih panjang dibandingkan dengan ukuran panjang badan sapi lainnya, jika dibandingkan dengan ukuran kakinya terlihat ukuran badan yang panjang namun pendek. Beragam keturunan dan spesies yang telah berevolusi dalam berbagai lingkungan merupakan bentuk yang unik dari keanekaragaman genetik yang terdapat dalam suatu populasi, dan ini tercermin dalam perbedaan morfologi, fisiologi dan perilaku antara individu dan populasi (Frankham et al. 2002). Pengukuran dimensi tubuh telah digunakan pada ternak besar untuk membandingkan variasi pada ukuran dan bentuk ternak tersebut (Gilbert et al. 1993; Lanari 2003). Dimensi tubuh ini juga telah digunakan untuk estimasi bobot hidup (Shahin et al. 1995; Yakubu et al. 2005). Pengukuran morfometrik telah digunakan untuk mengevaluasi karakteristik berbagai keturunan dari ternak, dan dapat memberikan informasi yang berguna pada kesesuaian seleksi untuk ternak (Yakubu 2010).

Tabel 2. Tampilan morfologis sapi Peranakan Angus

\begin{tabular}{lclll}
\hline \hline Umur (gigi) & Jumlah (ekor) & \multicolumn{1}{c}{ LD $(\mathrm{cm})$} & TG $(\mathrm{cm})$ & PB $(\mathrm{cm})$ \\
\hline $\mathrm{I}_{0}$ & 10 & $144,04 \pm 27,64$ & $112,13 \pm 14,71$ & $108,90 \pm 20,78$ \\
$\mathrm{I}_{1}$ & 6 & $162,46 \pm 7,93$ & $122,06 \pm 4,79$ & $121,98 \pm 6,55$ \\
$\mathrm{I}_{2}$ & 13 & $166,40 \pm 12,09$ & $126,91 \pm 2,80$ & $124,30 \pm 6,28$ \\
$\mathrm{I}_{3}$ & 9 & $167,55 \pm 8,55$ & $127,27 \pm 5,85$ & $131,03 \pm 7,16$ \\
$\mathrm{I}_{4}$ & 61 & $169,33 \pm 10,50$ & $127,75 \pm 5,47$ & $131,26 \pm 8,14$ \\
\hline
\end{tabular}

Pengukuran tubuh juga penting dalam memberikan informasi tentang struktur morfologi dan pengembangan kemampuan ternak tersebut (Pesmen \& Yardimen 2008). Struktur morfologi memberikan informasi penting untuk digunakan dalam karakterisasi dari populasi ternak, dan memungkinkan penilaian potensi produksi berdasarkan pada hubungan mekanik dalam struktur morfologi (Yakubu et al. 2010). Hal ini sesuai dengan kearifan lokal petani peternak di Kabupaten Sragen yang melaksanakan pemilihan sapi Peranakan Angus dengan mengarahkan kemampuan sapi memanfaatkan pakan berkualitas kurang baik dengan basis jerami padi dan toleran terhadap kondisi lingkungan tropis. Morfologi menunjukkan hubungan yang kuat dengan potensi produksi, karena mengandung struktur yang mendukung fungsi biologis. Jika hubungan ini tidak dianggap, berarti model adaptasi kehidupan tidak akan benar (Alpak et al. 2009). 


\section{Kemampuan koefisien teknis reproduksi sapi Peranakan Angus}

Nilai teknis reproduksi sapi Peranakan Angus sangat baik apabila didasarkan pada jarak beranaknya yang berkisar antara 12-15 bulan. Bahkan ada sapi Peranakan Angus mempunyai nilai jarak beranak kurang dari 12 bulan. Catatan terbaik untuk paritas induk sapi Peranakan Angus adalah 14 kali beranak. Nilai rata-rata populasi untuk skor kondisi tubuh sapi sebesar $2,71 \pm 0,23$. Informasi yang diberikan oleh peternak menyatakan bahwa jarang sekali terjadi kematian pedet. Hal ini menunjukkan bahwa produksi susu sapi Peranakan Angus cukup untuk mendukung pertumbuhan pedet yang cenderung lebih cepat (kemampuan produksi susu yang cukup tinggi ini diduga diturunkan dari sapi Aberdeen Angus yang merupakan salah satu bangsa pembentuknya) dan juga tetap mampu mempertahankan kondisi tubuh yang cukup baik.

Hubungan antara ukuran tubuh dengan kemampuan produksi dan reproduksi hasil beberapa penelitian dilaporkan mempunyai korelasi yang kuat antara beberapa ukuran tubuh secara linear dengan beberapa sifat produksi (Abdel-Moneim et al. 2009). Pengukuran struktur morfologi yang terkait perubahan kinerja produksi daging (panjang badan, lingkar dada). Oleh karena itu dalam proses seleksi yang berkelanjutan, tidak hanya perubahan sifat kualitatif tetapi juga sifat produktif yang diukur (Yakubu 2010; Yakubu et al. 2010)

Kondisi ini menunjukkan bahwa peternak telah mampu memanfaatkan daya dukung lingkungan untuk memelihara dan menjaga skor kondisi tubuh sapi Peranakan Angus, serta sapi tersebut telah mampu beradaptasi secara baik dengan lingkungan dan tatalaksana pemeliharaan. Berdasarkan informasi sifat produksi dan reproduksi, sifat kuantitatif dan sifat kualitatif sapi Peranakan Angus tersebut, dapat digunakan sebagai salah satu dasar program pemuliaan ternak, yaitu kriteria seleksi, karena sifat-sifat tersebut dapat diukur, mempunyai nilai korelasi dengan sifat-sifat lain yang bernilai ekonomi, serta respon terhadap seleksi individu (Boligon et al. 2010). Karakterisasi struktur genetik populasi dan hasil turunan memberikan informasi yang diperlukan untuk mengembangkan strategi program pemuliaan, karena memungkinkan studi variabilitas genetik. Informasi ini juga penting bagi program konservasi genetik (Thieu et al. 2010).

Oleh karena itu dalam rangka mempertahankan kemurnian ternak sekaligus meningkatkan performa genetik keturunannya, maka perlu dilaksanakan perbaikan mutu genetik sapi Peranakan Angus dengan menerapkan metode pemuliaan melalui program seleksi dan pengaturan perkawinan (Istiqomah 2010). Seleksi dan pengaturan perkawinan adalah cara prinsip yang digunakan untuk melaksanakan perubahan struktur genetik pada suatu populasi ternak, sehingga diperlukan pemahaman yang luas terhadap penentuan sifat yang ingin ditingkatkan dan diwariskan dari tetua kepada keturunannya (Segura 1998).

\section{KESIMPULAN}

Sapi Peranakan Angus merupakan salah satu hasil pelaksanaan program IB yang mampu berkembang dan beradapatasi dengan kondisi tropis khususnya di Kabupaten Sragen. Kemampuan produksi dan reproduksi sapi Peranakan Angus sangat baik sehingga dapat digunakan untuk program pemuliaan sapi penghasil daging. Sapi Peranakan Angus berdasarkan waktu dan proses terbentuknya dapat diarahkan menjadi kandidat rumpun baru sapi potong Indonesia. Guna menjaga kelestarian sapi Peranakan Angus, maka perlu dilakukan perwilayahan pengembangan sapi Peranakan Angus maupun sapi PO di Kabupaten Sragen melalui pembuatan Peraturan Daerah 


\section{UCAPAN TERIMA KASIH}

Penulis menyampaikan terima kasih kepada tim teknisi yang telah membantu pelaksanakan pengambilan data, tim penelitian Sumber Daya Genetik Sapi Potong Lokal Indonesia Loka Penelitian Sapi Potong. Ucapan terima kasih selanjutnya penulis menyampaikan kepada Dinas Peternakan dan Perikanan Kabupaten Sragen, dan BPTP Jawa Tengah yang telah memberikan bantuan dan masukan dalam pelaksanaan kegiatan penelitian dan pengambilan data.

\section{DAFTAR PUSTAKA}

Abdel-Moneim AY. 2009. Use of live body measurements for prediction of body and carcass cuts weights in three Egyptian breeds of sheep. Egyptian J Sheep Goat Sci. 2:17-32.

Adinata Y, Aryogi. 2015. Karakter fenotipik sapi Rambon Betina di Kabupaten Banyuwangi. Prosiding Seminar Nasional Pengembangan Sumber Daya Genetik Pertanian. Bogor, 27 Mei 2015. Bogor (Indonesia): BBPPTP. hlm. 512-520.

Adrial. 2010. Potensi sapi Pesisir dan upaya pengembangannya di Sumatera Barat. J Litbang Pertan. 29:66-72.

Alpak H. Onar V, Mutus R. 2009. The relationship between morphometric and long bone measurements of the Morkaraman sheep. Turkish J Vet Anim Sci. 33:199-207.

Astuti M. 2004. Potensi dan keragaman sumber daya potensi genetik sapi Peranakan Ongole (PO). Wartazoa. 14:98-106.

Boligon AA, Silva JAV, Sesana RC, Sesana JC, Junqueira JB, Albuquerque LG. 2010. Estimation of genetic parameters for body weight, scrotal circumference and testicular volume measured at different ages in nellore cattle. J Anim Sci. 88:1215-1219.

Delgado JV, Barba C, Camacho ME, Sereno FTPS, Martinez A, Vega-Pla JL. 2001. Livestock characterisation in Spain. Anim Genet Resour Information. 29:7-18.

Frankham R, Ballou JD, Briscoe DA. 2002. Introduction to conservative genetics. Cambridge (United Kingdom): Cambridge University Press.

Gilbert RP, Bailey DRC, Shannon NH. 1993. Linear body measurements of cattle before and after 20 years of selection for post-weaning gain when fed two different diets. J Anim Sci. 71:17121720.

Istiqomah L. 2010. Kemajuan genetik sapi lokal berdasarkan seleksi dan perkawinan terpilih. Widyariset. 13:63-67.

Diwyanto K, Inounu I. 2009. Dampak crossbreeding dalam program inseminasi buatan terhadap kinerja reproduksi dan budidaya sapi potong. Wartazoa. 19:93-102.

Lanari MR, Taddeo H, Domingo E, Centeno MP, Gallo L. 2003. Phenotypic differentiation of exterior traits in local Criollo goat population in Patagonia (Argentina). Arch Tierz Dummerstorf. 46:347-356.

Metta M, Kanginakudru S, Gudiseva N, Nagaraja J. 2004. Genetic characterization of the Indian cattle breeds, Ongole and Deoni (Bos indicus), using microsatellite markers - a preliminary study. BMC Genet. 5-16.

Pesmen G, Yardimen M. 2008. Estimating the live weight using some measurements in Saanen goats. Archive Zoo Technic. 11:30-40.

Riva J, Rizzi R, Marelli S. Cavalchini LG. 2004. Body measurements in Bargamasca sheep. Small Rumin Res. 55:221-227. 
Rutter L, Engstorm D, Hand R. 2000. Body condition: implication for managing beef cows. Alberta Agriculture and Rural Development, California. Agdex. 420/40-1.

Segura AHYC. 1998. Heritability performance in brahman cattle. Trop Anim Prod. 5:46-49.

Setiadi B, Diwyanto K. 1997. Karakteristik morfologis sapi Madura. JITV. 2:218-224.

Shahin KA, Soliman AM, Moukhtar AE. 1995. Sources of shared variability for the Egyptian cattle body shape (conformation). Indian J Anim Sci. 65:759-764.

Siregar AR, Situmorang P, Diwyanto K. 1997. Pemanfaatan teknologi Inseminasi Buatan (IB) dalam usaha peningkatan produktivitas sapi potong di Indonesia. Prosiding Seminar Nasional Teknologi Peternakan dan Veteriner. Bogor (Indonesia): Puslitbangnak. hlm. 171-186.

Thieu PX, Georgescu SE, Manea MA, Hermenean AO, Costache M. 2010. Genetic diversity and phylogenetic relationships of Romanian cattle breeds inferred from cytochrome $\mathrm{b}$ gene partial sequences. Rom Biotechnol Letters. 15:5154-5158.

Trifena, Budisatria IGS, Hartatik T. 2011. Perubahan fenotip pada sapi Peranakan Ongole, Simpo, dan Limpo pada keturunan pertama dan keturunan kedua (backcross). Bul Peternak. 35:11-16.

Yakubu A, Salako AE, Imumorin IG, Ige AO, Akinyemi MO. 2010. Discriminant analysis of morphometric differentiation in the West African Dwarf and Red Sokoto goats. South Afric J Anim Sci. 40:381-7.

Yakubu A, Salako AE, Ogah M, Ari MM. 2005. Relationship between body weight and chest girth in White Fulani cattle. J Nat Appl Sci. 1:17-21.

Yakubu A. 2010. Path coefficient and path analysis of body weight and biometric traits in Yankasa lambs. Slovak J Anim Sci. 43:17-25.

\section{DISKUSI}

\section{Pertanyaan}

Sapi Peranakan Angus bisa diarahkan ke produksi daging karena telah disebutkan mempunyai performa baik, seperti yang sekarang sedang dikembangkan adalah sapi Bali. Apabila dibandingkan dengan sapi Bali lebih menguntungkan yang mana? Bagaimana harga jual sapi Peranakan Angus dibandingkan dengan sapi Brahman dan sapi PO? Apa mungkin diintegrasikan dengan sapi sawit?

\section{Jawaban}

Saat ini belum ada program tersebut. Belum ada kajian ekonomi sapi Peranakan Angus. Peternakan sapi Peranakan Angus ini di Sragen dijadikan percontohan pertanian organik, jadi kotoran sapi untuk pupuk. Sapi Peranakan Angus juga dikenal toleran terhadap kondisi di lokasi yang agak berkapur. Untuk perbandingan dengan sapi Bali belum bisa dijawab karena belum ada data, tetapi yang menarik dari sapi Peranakan Angus ini belum pernah dilaporkan kejadian "neonatal". Pada waku yanng akan datang apabila produksi sudah banyak dapat diintegrasikan dengan sawit. Saat ini ada permintaan untuk Nusa Tenggara Barat karena kondisi alam yang agak mirip dengan Sragen. Sapi Peranakan Angus jantan laku keras untuk penggemukan karena lebih cepat besar bila dibandingkan dengan yang betina. 